THURSDAY, MARCH 25, 1920.

\section{Knowledge and Power.}

$\Gamma_{\text {is widely recognised, the majority of the }}^{\text {in }}$ important problems that have to be handled are largely technical in character; this is so whether these problems lie in the broad domain of national policy, in the narrower limits of administrative action, or in the restricted fields of executive performance. To this situation is due, as is well known, the need that has arisen in recent times for that high degree of specialisation in certain kinds of knowledge which has revolutionised the scheme of organisation of the personnel in the fields of commerce and industry, and is likewise responsible for the introduction, in many enterprises throughout the world, of the régime of the expert.

Being, comparatively speaking, a newcomer in the realms of officialdom, the modern technical expert has still to be assigned his place of precedence there, and at the same time to have the scope of his authority and the dignity of his status definitely determined and unequivocably declared. These are matters calling for early attention, for a suspicion exists, not without foundation, that, whilst in commercial and industrial circles the expert has been very generally permitted to occupy a position of influence compatible with the importance of his métier, in the governmental sphere the expert has, more often than not, been relegated to a position in which his every purpose is rendered more or less ineffectual, one, moreover, in which the exercise of his legitimate activities is barely tolerated by those occupying the clerical or controlling positions.

During the past few years the prevailing uneasiness regarding the unsatisfactory footing on which the technical staff in the public services finds itself has been quickened, owing largely to an appreciation on the part of the public of the fact that it was the failure in governmental quarters to give heed to the advice of the technical expert that was responsible for bringing the country to the brink of a dire catastrophe-one, indeed, which, at the crisis of the late war, threatened its continued existence as an independent people, one from which it escaped with but a very narrow margin.

The British public had been persuaded to believe that any deficiency in the military No. 2630 , VOL. IO5] establishments of the country was more than counterbalanced and compensated for by reason of the high perfection to which every detail connected with the Royal Navy had been brought. In the circumstances, the public may well be pardoned for the belief so firmly held by it before the Great War that the British Navy had nothing whatever to learn from either friend or foe.

That the popular conceptions on the foregoing matters were in many respects erroneous now stands out in cold print in the pages of Lord Jellicoe's "The Grand Fleet, 1914-16." 1 In the preface to this book it is stated in unequivocal terms that the Germans were "superior to us in material." The gallant Admiral does not limit himself to generalisations, but on many a page he particularises the specific matters in which the equipment or arrangements on our battleships were deficient,.defective, or obsolete, and *our defence works wanting. For example, he states: "The Jutland battle convinced us that our armourpiercing shell was inferior in its penetrative power to that used by the Germans." "Some delay occurred in improving our range-finders. . . . Our most modern ships were provided with rangefinders ${ }_{5} \mathrm{ft}$. in length, but the majority of the ships were fitted with instruments only $9 \mathrm{ft}$. long. During I9I7 successful steps were taken to supply range-finders up to $25 \mathrm{ft}$. and $30 \mathrm{ft}$. in length; a series of experiments with stereoscopic range-finders was also instituted in the same year. It had become known that the Germans used this type of range-finders." "The use of smoke screens was closely investigated as a result of our experience of the German use of this device." "Neither our searchlights nor their control arrangements were at this time of the best type." The foregoing are but a few of the specific matters in which the foremost Navy in the world is recorded to have been outstripped, at a critical period of the war, by a rival of new creation.

In other directions, too, was Great Britain lacking in the matter of naval defence. For example, reference is made by Lord Jellicoe to the fact that harbour defences and obstructions were nonexistent in the early days of the war. Again, it is stated that in the matter of gunnery and torpedo practices considerable leeway had to be made good. As regards the former, after the outbreak of war a great extension of the system of director firing, by which one officer or man can

1 Published by Cassell and Co., Ltd. Price 3Is. 6\%. net. 
lay and fire all the guns of a ship, was made (in August, 1914, only eight battleships had been fitted with this system).

In the face of the disclosures made in connection with the Battle of Jutland, it may well be asked whether the deficiencies and defects to which attention has been directed could have been foreseen in peace time and provided against. Little doubt on the subject can be left in the minds of those who read in a spirit of inquiry "Fifty Years in the Royal Navy," the autobiography of Admiral Sir Percy Scott ${ }^{2}$; the matters dealt with therein provide a direct answer to the foregoing question. In many of the pages of this autobiography will be found the story of the striving, over a long period of years, after progress and efficiency in relation to various details connected with the Senior Service, and of the obstinate opposition to all reforms which was constantly met with by those who were in pursuit of essential improvements. The remarks of Sir Percy Scott on every subject the theme of which relates to the attempt to introduce into the public service some new idea or device, or some improvement on existing apparatus, machinery, or methods, have all the same ring about them. In relation to every one of the matters to which the distinguished Admiral refers, the conduct of those in the controlling positions was consistent; in every instance the advice and assistance of the expert were ignored, either until it was altogether too late, or until considerable harm had been done and the waste of much public money, if not also the loss of valuable lives, involved.

Sir Percy Scott tells us that it was so long ago as February 10, 1909, that battle practice first took place, at Tetuan, with extemporised director firing. Yet it took the Admiralty two years to come to a decision as to its introduction into the Navy, and the Board waited for eight yearsindeed, until the nation had for nearly three years been involved in a life-and-death struggle--before it adopted the system generally.

Another remarkable illustration of Admiralty methods mentioned by Sir Percy Scott is that connected with the depth charge, which ultimately turned out to be the antidote to the submarine. The design of a depth charge, actuated by a hydrostatic valve, was submitted by Capt. P. H. Colomb on October I, I9r4. The idea was so simple that these depth charges could have been

\footnotetext{
2 Published by John Murray. Price 2rs, net. NO. 2630, VOL. IO5]
}

supplied in large quantities within a few weeks of the date mentioned, but it was not until 1916 that a decision was arrived at on the matter; meanwhile, the delay, it is stated, involved the nation in a loss of $200,000,000 l$.

A similar striking example of officialism occurred in relation to the Pomeroy bullet, which was eventually successfully used in attacking Zeppelins. This bullet had been first tried in Igo8, and gave satisfactory results; it was submitted to the War Office in 59I4, but rejected. In June, I9I5, another trial was made of the bullet, and again it proved satisfactory; however, it was not accepted and brought into use until the autumn of I916-that is to say, the country had to wait two years for the adoption of an essential missile which was urgently wanted, in spite of the fact that the efficacy of the invention had been unmistakably proved many years previously.

Instances of official ineptitude and bureaucratic formalism similar to those referred to in the foregoing examples, and others mentioned in Sir Percy Scott's autobiography, are, unfortunately, all too common in practically every Government Department in this country, and arise all from the same cause, the ignoring of the advice and opinions of the technical expert and a fixed distrust of him. Expression was given to this attitude a few years ago by an official of the administrative branch of a Government Department during an inquiry before a Select Committee of the House of Commons into an important engineering contract--a contract in which the technical staff had been entirely ignored at every stage connected with its negotiation. "I do not think," said this official, "these gentlemen, the highly technical experts, are suited, by their education or their environment and line of thought, and all that sort of thing, to decide very often what is the best thing to do. They jump to a conclusion." Yet the most superficial examination of the evidence that exists in relation to the measures and steps by which the technical expert has succeeded in providing man with the material comforts enjoyed by him, and by which there have been placed at the command of the business community the powerful aids to commerce and industry comprised in the domain of the public utility services, affords the most complete contradiction of the mischievous doctrine contained in the foregoing utterance.

It must not be imagined that it is alone in relation to questions of high policy, such, for 
example, as the Dardanelles Expedition-with regard to which it is recorded in Lord Fisher's "Memories" 3: "The Cabinet Council reached its conclusions without drawing the opinion of the expert thereat for its guidance"--that the technical experts are ignored; on the contrary, many examples can be given of instances when, in relation both to important technical aspects of departmental policy and to simple matters of executive detail, the advice of the technicians has been overruled or not sought.

The root cause of the mischief under discussion lies in the system of the Civil Service. A privileged class has been allowed to grow up there, a class which, by reason of its proximity to the Minister and of the long service of the individual members composing it in one particular office, has obtained too great an influence, and is thus enabled to exercise an ascendancy not only over Ministers, who flit through their Departments, but also over those officials whose early years are spent on executive and technical duties.

The remedy for the present unsatisfactory state of affairs as regards the position of the technical expert is not far to seek. As matters stand to-day, the technical staffs in the Government Departments have too little influence and authority, whilst the Civil Service clerk has too much influence and an excess of authority. The disparity between the powers of these two classes is a source of public danger, and the way to obviate it is by a thorough reorganisation of the Civil Service and its system. What is required is that the chief administrative posts shall forthwith cease to be a monopoly of the clerical staffs. A suitable organisation for the Civil Service would be one which provided that entrants into every branch of it should, as a rule, begin their careers in an executive grade, and be promoted to occupy administrative posts at the headquarters of a Ministry or Department only after giving proof that they were familiar with the practical aspects of the matters they might be called on to administer. By the introduction of such an organisation into the Civil Service, it would be possible to select the best qualified officers in each branch for the important administrative posts, and, in consequence, render possible the adoption of a system whereby all matters referred to headquarters on which decisions have to be passed would come invariably before those who were experts in the particular subject upon which action had to be taken.

\footnotetext{
3 Published by Hodder and Stoughton. Price zis. net. No. 2630 , VOL. IO5]
}

\section{Aeronautical Research.}

Applied Aerodynamics. By Leonard Bairstow. Pp. xii +566 . (London: Longmans, Green, and Co., 1920.) Price 32s. net.

MPATIENTLY as we have waited for the publication of this book, we feel that its appearance could scarcely have been more opportune. For here, as we believe, will be found abundant evidence in support of those who, like the Committee for Education and Research in Aeronautics, have striven to resist the break-up of our aerodynamics laboratories and design staffs. Research is always costly, aeronautical research superlatively so; and a public whose ear has been somewhat dulled by the insistence with which its claims were urged-not always wisely-during the war is somewhat naturally deafened now, by strident calls for economy, to any temperate statement of its claims. It is not promises that are wanted at the present time, to justify further expenditure, but a record of things achieved; and although the tangible results of British science and invention, as applied to the construction of aircraft, have appealed, and by the glamour of long-distance flying are still appealing, to the popular imagination, yet it has resulted from secrecy necessary in war time that the foundations upon which these successes have been built - the patient, detailed investigations which have supplied our designers with the data they required - are familiar only to a very few, being for the most part contained in reports of which the circulation, no less than the appeal, has been limited to specialists.

Now, within one volume of reasonable dimensions and large type, we are presented with an authoritative review of the work achieved by our research organisations during five years of strenuous activity. We have no fears that impartial judgment will pronounce the time and expenditure to have been wasted. Most branches of applied science have developed rapidly under the stimulus of war conditions, but of applied aerodynamics it might without serious exaggeration be said that the science has been created. The pioneer work is done, but to those who read Mr. Bairstow's book carefully it will be evident that on every side lie fields for research of which scarcely the surface has been broken, and that no mistake could be more disastrous, if we acknowledge the importance of aeronautics, than a refusal now to avail ourselves of the experience acquired by those few men to whom its present state of development is due.

We do not, of course, imply that the book is 